\title{
ЗДАТНІСТЬ ДО ПРОГНОЗУВАННЯ ЯК УМОВА УСПІШНОЇ ПРОФЕСІЙНОЇ ДІЯЛЬНОСТІ ДОРОСЛИХ
}

\author{
Свгенія Резвих \\ аспірантка кафедри теоретичної та консультативної психології \\ Національний педагогічний університет імені М.П. Драгоманова \\ 01601, україна, м. Київ, вул. Пирогова, 9 \\ rezvykh.evgeniya@gmail.com, http://orcid.org/0000-0001-5316-0516
}

\begin{abstract}
Анотація
У статті презентовано результати теоретичного дослідження психологічних джерел 3 проблеми прогнозування професійної діяльності дорослих. Розкрито теоретико-методологічні положення вивчення прогнозування та життєвого прогнозування як психологічних феноменів у працях зарубіжних та вітчизняних психологів. Визначено зміст і сутність прогнозування діяльності та професійної діяльності людини. Виокремлено два етапи вивчення досліджуваної теми: класичний і сучасний. Представники класичної психології розкривають прогнозування діяльності людини в контексті іiі функціонування на сенсорному та розумовому рівнях психічного відображення. Сучасні психологи в своїх дослідженнях ставлять акцент на розвитку прогностичних здібностей і вмінь молоді та дорослих у процесі фахової підготовки. Зосереджено увагу на взаємозв'язку здатності дорослої особистості до прогнозування власного майбутнього, своїх життєвих цілей і планів 3 прогнозуванням іiї професійної діяльності. Доведено, що здатність до прогнозування $\epsilon$ ключовою умовою успішної професійної діяльності особистості в дорослому віці. Емпірично виявлені психологічні особливості прогнозування життєвих і професійних планів дорослих та успішної їх реалізації. За результатами проведеного аналізу аналітичності, усвідомленості, гнучкості, перспективності та доказовості життєвого та професійного прогнозування встановлено, що в прогнозах на майбутнє аналітична функція дорослих обмежена, усвідомленість майбутнього пов'язана з причинно-наслідковими співвідношеннями, гнучкість цілей та планів визначає адаптивність до стрімких змін сьогодення, перспективність має темпоральні характеристики в життєвому просторі дорослих, а доказовість відображає процеси аналізу життєвих ситуацій минулого для здійснення більш точного прогнозу майбутнього. Констатовано, що лише високий інтегральний показник здатності до професійного прогнозування дорослих, може забезпечити успішність їх професійної самореалізації. Підкреслено значущість для подальшого вивчення процесу прогнозування професійної діяльності представниками різної статі.
\end{abstract}

Ключові слова: прогнозування, життєве прогнозування, прогнозування професійної діяльності, перспективність життєвого та професійного прогнозування, здатність до прогнозування, прогнозування успішної професійної діяльності, особистість дорослого віку.

\section{Ветуп}

Трансформація українського ринку праці спричинена мобільністю населення, використанням цифрових технологій та процесами глобалізації в усіх сферах життя, що зумовлює необхідність посилення уваги психологічної науки до вивчення питань, що 
пов'язані з професійною діяльністю дорослих. Крім того, сучасні та швидко змінні умови життя висувають нові вимоги до особистості професіонала, оскільки виникає потреба щодо передбачення наслідків їі діяльності. Адже на сьогодні зростає значущість не лише можливих позитивних досягнень особистості, але й втрачених нею можливостей та допущених помилок.

Професійна діяльність як основна форма соціальної активності дорослої людини відіграє визначну роль у самоствердженні, самовизначенні, особистісному та професійному розвитку та життєдіяльності в цілому. Водночас, дослідниками в галузі психології (І. Булах, Ж. Вірна, Л. Помиткіна, В. Чернобровкіна), все більше виявляються негативні тенденції та труднощі самореалізації й особистісного зростання людини в дорослому віці, що значною мірою ускладнює процес прогнозування нею свого власного життя, в тому числі й професійного. Насамперед, це прагнення жити «тут і тепер», інфантильність, низький рівень саморефлексії, прокрастинація життєвих і професійних виборів, особистісна незрілість, зневіра в можливості професійної самореалізації в наявних соціально-економічних умовах все це значною мірою ускладнює й обмежує можливості побудови дорослою людиною свого життєвого та професійного простору. У зв'язку з цим особливої актуальності набуває вивчення проблеми прогнозування професійної діяльності у дорослому віці.

Мета дослідження полягає в теоретичному аналізі проблеми прогнозування професійної діяльності дорослих та емпіричному вивченні здатності до прогнозування як умови їх успішної професійної самореалізації. Завдання дослідження: 1) провести теоретикометодологічний аналіз наукових праць за обраною тематикою; 2) за результатами емпіричного дослідження здійснити якісний аналіз сформованості здатності дорослих до професійного прогнозування.

\section{Методи дослідження}

У процесі вивчення здатності прогнозування дорослими нами було використано цілий ряд методів, серед яких теоретичні та емпіричні. У процесі вивчення наукових джерел здійснено теоретичний аналіз доробок вчених з проблеми дослідження прогнозування в дорослому віці. Аналіз та синтез надав можливість виокремити методологічні засади досліджуваного психологічного явища та систематизувати й обгрунтувати вихідні положення його дослідження. У ході емпіричного дослідження були використані метод спостереження, бесіда та тестування з використанням методики «Здатність до прогнозування» (авт. Л. Регуш, в модиф. С. Резвих). Для виводу кількісних даних результатів дослідження в графічну форму була використана програма excel for windows (версія office 365).

Дослідження проводилося на базі групи компаній «Укргаз». Вибірку становили 104 досліджуваних - керівники вищої й середньої ланки управління та спеціалісти віком від 22 до 55 років.

\section{Результати та дискусії}

Проблема прогнозування професійної діяльності ще досить нова та недостатньо вивчена. Узагальнюючи проаналізовані наукові джерела вчених, які займались цією проблемою, можна визначити прогнозування як процес формування ймовірнісного судження про стан явища, що, або пізнається, або реалізується в майбутньому. Близькими, але неідентичними за значенням, як стверджують Г. Кошонько та О. Поробок, до терміну «прогнозування» $є$ поняття: «передбачення» та «антиципація». Прогнозування від перерахованих процесів відрізняється алгоритмізованістю, а результат - інформація про 
прогнозоване майбутнє (прогноз) - більш точна, об’єктивна й обгрунтована. Здійснюючи будь-яку діяльність, людина прогнозує ії результат і передбачає хід подій. Залежно від мети, вона може здійснювати безпосередній вплив на діяльність та змінювати своє майбутнє (Кошонько \& Поробок, 2018).

Питання прогнозування та життєвого прогнозування дорослої особистості висвітлені в низці наукових праць зарубіжних і вітчизняних дослідників. Так, К. Абульханова-Славська, досліджуючи прогнозування життєвих цілей та планів, визначила сутність життєвого прогнозування як потенціал, можливості особистості, що об'єктивно складаються у теперішньому, та будуть виявлятися в майбутньому у вигляді життєвих перспектив і життєвої стратегії (Абульханова-Славская, 1980).

I. Бестужев-Лада в процесі вивчення соціального прогнозування розглядав його як інструмент наукового дослідження, предметом якого може бути вивчення перспектив розвитку соціальних явищ та подій. У процесі прогнозування людина, за науковою позицією вченого, описує можливі або бажані перспективи, події, засоби вирішення проблем у майбутньому. Цей процес пов'язується особистістю з вирішенням зазначених проблем, використанням інформації про майбутнє для цілеспрямованої іiі життєдіяльності та професійної самореалізації (Бестужев-Лада, 1982).

Український вчений С. Максименко завдяки методологічним положенням розвитку прогнозування актуалізував питання психічного здоров'я особистості та розкрив поняття «метапрогнозування». На його думку, доросла людина майже ніколи не прогнозує власний розвиток, вона прогнозує - досягнення, життєві ситуації, умови існування з іншими людьми, особливості життя своїх дітей тощо. Отже, як зазначив вчений, майбутнє набагато більше детермінує розвиток особистості, ніж минуле (Максименко, 2010).

У наукових працях вітчизняного дослідника I. Батраченко, прогнозування розглядалось як універсальний компонент будь-якої активності людини та презентувалося як процес отримання інформації, що випереджає в часі. Водночас, прогнозування поєднує в собі два процеси: антиципацію (випереджальне відображення) та творення майбутнього (проєктування) (Батраченко, 1996).

Життєве прогнозування особистості забезпечує організацію нею діяльності у відповідності з уявленнями про своє бажане майбутнє та можливість іiі реалізації в сучасних умовах. Так, згідно з науковою позицією М. Ляхової, життєве прогнозування являє собою форму або спосіб свідомого планування та конструювання людиною власного життя у відповідності з властивою їй системою цінностей, смислів і цілей (Ляхова, 2010). Ефективність життєвого прогнозування особистості зумовлює успішність іiі життєвої та професійної діяльності. Життєве прогнозування орієнтоване на передбачення власного майбутнього, створення бажаного образу, постановку цілей та планів у різних сферах активності особистості: навчання, сімейні стосунки, професійна самореалізація тощо.

Отже, вважаємо, що за своїм змістом поняття життєве прогнозування особистості охоплює як найближче, так і віддалене майбутнє в її бажаннях та очікуваннях. На нашу думку, прогнозування людиною професійної діяльності тісно переплітається з процесом професійної реалізації та завжди має простір для самореалізації у професії відповідно до своїх індивідуальних здатностей. У цілому, узагальнюючи всі вище зазначені позиції зарубіжних та вітчизняних вчених, можна зробити висновок, що прогнозування - це мисленнєва активність людини, результатом якої є передбачення шляхів розвитку власного майбутнього. У свою чергу прогнозування професійної діяльності можна окреслити як особистісне уявлення, оцінку 
та тлумачення подальшого розвитку особистості в професійній сфері, що включає професійні цілі та плани, шляхи їх досягнення, уявлення про кар'єрне зростання та підвищення власного професіоналізму.

Систематизуючи та синтезуючи результати теоретичного дослідження, ми виділили два етапи вивчення проблеми прогнозування професійної діяльності людини. Перший етап можна умовно назвати класичним, другий сучасним.

Класичними є роботи Б. Ломова та Є. Суркова, якими систематизовано знання про антиципацію як випереджувальне відображення. Цей рівень відображення виступає як здатність діяти та приймати ті чи інші рішення 3 відповідним часово-просторовим випередженням щодо майбутніх подій. Вчені, залежно від типу завдань, що вирішувалися у процесі будь-якої діяльності, виокремили п'ять якісних рівнів антиципації: сенсомоторний, перцептивний, уявленнєвий, мовно-розумовий, субсенсорний. Кожен з означених рівнів, взаємодіючи між собою, становили функціональну систему прогнозування. Специфіка їх інтеграції залежить від мети та завдань діяльності, що спрямовують випереджальний пошук (Ломов \& Сурков, 1980). Отже, процес прогнозування $є$ необхідною умовою планування діяльності особистістю дорослого віку.

У зв'язку з попередньо визначеними досягненнями Б. Ломова та Є. Суркова, доречно звернутись до наукової позиції І. Бестужева-Лади. Вчений, досліджуючи контекст соціального прогнозування, констатував також цілеспрямований характер життєвого та професійного прогнозування - наявність свідомої мети, яка відрізняє їх від інших форм випереджального відображення (Бестужев-Лада, 1982).

У процесі вивчення прогностичної функції розумової діяльності людини А. Брушлінський довів, що саме прогнозування визначає обгрунтованість, економічність і правильність прийняття рішень (Брушлинский, 1979).

Отже, представниками класичної психології була презентована прогностична діяльність особистості та специфіка iï функціонування на сенсорному, перцептивному, розумовому та інших рівнях психічного відображення, а сутнісна основа прогнозування була визначена як перцептивно-розумова діяльність особистості, яка надає ій можливість вирішувати різні види життєвих та професійних завдань.

На сучасному етапі вивчення проблеми прогнозування, вчені (М. Краєва, Л. Регуш, Н. Соколова та ін.) досліджували здібності та вміння людей різного віку й представників різних професій, що надало їм можливість довести вплив сформованої здатності людини до прогнозування на успішність іiі професійної діяльності (Краева, 1999; Регуш, 2003; Соколова, 2004).

Показово в цьому плані, що М. Краєва, досліджуючи прогностичні здібності в професійному розвитку студентів, виділила загальні та професійні прогностичні здібності й визначила їх структуру та рівні. У структурі прогностичних здібностей було констатовано емоційний, когнітивний і поведінковий компоненти. Вчена довела, що прогностичні здібності, як системні психологічні утворення, мають три рівні розвитку: 1 рівень - прогноз на основі ставлення, переживання; 2 рівень - прогноз на основі пізнання; 3 рівень - прогноз зворотного зв'язку, регуляції діяльності. Перший (базовий) рівень відображає загальну здатність до прогнозування; другий (професійний) - розкриває значущі здібності, які визначають якість процесу прогнозування; третій рівень - результат (наслідки) діяльності (Краева, 1999).

Прогнозування як пізнавальну здатність особистості досліджувала Л. Регуш. За науковою позицією вченої, «знання про майбутнє становлять «основний продукт» 
пізнавальної прогностичної діяльності людини, а її мета - отримання прогнозу» (Регуш, 2003: 88). Пізнавальна прогностична здатність - це сукупність якостей розумових процесів, що визначають успішність пізнавальної прогностичної діяльності суб'єкта. Л. Регуш стверджувала, що в структурі прогностичних здібностей можна виділити конкретні якості розумових процесів: аналітичність, глибину, усвідомленість, гнучкість, перспективність і доказовість мислення. Рівень розвитку цих якостей забезпечує ефективність прогностичної діяльності особистості, а ефективність прогнозування професійній діяльності дорослої людини залежить від змістового боку прогнозування - професійних знань (Регуш, 2003).

Іншу позицію мала Н. Соколова, котра визначила прогнозування як пізнавальну діяльність, що грунтується на накопиченому досвіді та на поточних припущеннях щодо майбутнього. Прогностичну здатність вчена зводить до таких вмінь: вміння передбачати та науково досліджувати розвиток будь-яких процесів, а також вміння передбачати наслідки прогнозів при вирішенні професійних завдань. Отже, на думку вченої, здатність прогнозування професійної діяльності дозволяє людині інтерпретувати отримані результати в процесі виконання професійних завдань, визначати наслідки здійснених прогнозів, здійснювати корекцію та розробку рекомендацій для визначення мети, побудови планів, програм, проєктів, визначити оптимальні умови для успішного функціонування та розвитку (Соколова, 2004).

За науковою позицією А. Захарова, прогностична здатність - це система теоретичних дій і операцій, які спрямовані на отримання випереджальної інформації про об'єкт (суб’єкт) дійсності. При цьому вчений відзначив, що формування прогностичних вмінь - це спеціально організований, цілеспрямований процес 3 опановування всією сукупністю дій, які забезпечують отримання випереджальної інформації про найбільш ймовірнісні тенденції розвитку об’єктів чи суб'єктів дійсності (Захаров, 2009).

Здатність до прогнозування, як підкреслила І. Блохіна - це процес передбачення майбутнього, що заснований на ймовірнісній структурі минулого досвіду та інформації про поточну ситуацію. Ця здатність, як було вказано вченою, є однією з необхідних здібностей фахівця з управління навчальними закладами (Блохіна, 2012).

У процесі дослідження здатності до прогнозування в майбутніх працівників правоохоронних органів Є. Анфалов довів, що здатність до прогнозування $\epsilon$ фундаментальною властивістю психіки, яку можна визначати як загальну й як спеціальну. Саме здатність до прогнозування розвивається та виявляється в професійній діяльності людини (Анфалов, 2016).

О. Гріньова досліджувала проєктування особистістю життєвого шляху та визначила його як процес екзистенційно-суб'єктного втілення особистістю інтенцій свого буття в особистісних і соціальних вимірах життєвого світу. Проєктування особистості, на думку вченої, має суб'єктний характер та спрямоване на авторське творення проєкту свого майбутнього. Стрижневою інтенцією життєпроєктування є смисложиттєвий пошук, одним 3 механізмів реалізації якого є прогнозування особистістю власного майбутнього. Цікавою, на нашу думку, є презентована структура життєпроєктування. О. Гріньова виділила компоненти цієї структури, а саме: інтимно-особистісний, професійний, етнічний, духовні лінії життєвого проєкту та метапроєктування. Вона довела, що метапроєктування структурує смисложиттєві орієнтації - життєві цілі, плани, перспективи, стратегії, авторське проєктування життєвого шляху. Базисом розгортання професійної лінії життєпроєктування в особистісному світі вчена визначила ціннісні орієнтації (Гріньова, 2018). 
Покладаючись на результати теоретичного аналізу наукових доробок вчених, можемо констатувати, що сучасні дослідники по-різному визначають «прогностичну здатність» та розходяться в поглядах на можливості іiі розвитку. Водночас, більшість дослідників визначають нерозривний взаємозв'язок прогнозування професійної діяльності в дорослому віці зі здатністю прогнозування особистістю свого власного майбутнього, своїх життєвих цілей і планів. Вчені сходяться на думці про те, що прогностична здатність є обов'язковою умовою ефективності й успішності самореалізації дорослої людини в професії. Зазначена наукова позиція вчених була підтверджена результатами дослідження Є. Головахи про існування залежності між задоволеністю життям і здатністю здійснювати вибір професії. При цьому задоволеність особистістю життям впливає на почуття іiі впевненості в своєму майбутньому, формуючи у неї певну установку на самореалізацію в професійній діяльності (Головаха, 2002).

Спираючись на презентовані нами наукові положення вчених, ми провели емпіричне дослідження здатності до прогнозування в керівників вищих й середніх ланок управління та спеціалістів. Розподіл одержаних кількісних результатів у процесі дослідження учасників експерименту наведений у табл. 1.

Таблиия 1

Кількісні показники розвитку здатності до прогнозування особистості дорослого віку

\begin{tabular}{|c|c|c|c|}
\hline \multicolumn{2}{|c|}{$\begin{array}{c}\text { Рівень розвитку здатності до } \\
\text { прогнозування }\end{array}$} & \multicolumn{2}{|c|}{ Досліджувані } \\
\hline Шкала & Рівень & Абс. к-сть & $\%$ \\
\hline \multirow{3}{*}{ Аналітичності } & Високий & 32 & $30,77 \%$ \\
\hline & Середній & 56 & $53,85 \%$ \\
\hline & Низький & 16 & $15,38 \%$ \\
\hline \multirow{3}{*}{ Усвідомленості } & Високий & 20 & $19,24 \%$ \\
\hline & Середній & 68 & $65,38 \%$ \\
\hline & Низький & 16 & $15,38 \%$ \\
\hline \multirow{3}{*}{ Гнучкості } & Високий & 28 & $26,92 \%$ \\
\hline & Середній & 64 & $61,54 \%$ \\
\hline & Низький & 12 & $11,54 \%$ \\
\hline \multirow{3}{*}{ Перспективності } & Високий & 36 & $34,62 \%$ \\
\hline & Середній & 52 & $50,00 \%$ \\
\hline & Низький & 16 & $15,38 \%$ \\
\hline \multirow{3}{*}{ Доказовості } & Високий & 42 & $40,38 \%$ \\
\hline & Середній & 54 & $51,92 \%$ \\
\hline & Низький & 8 & $7,69 \%$ \\
\hline
\end{tabular}

Результати за шкалою аналітичності прогнозування відображають спрямованість дорослих до всебічного та повного аналізу свого життя. Як видно 3 табл. 1., серед досліджуваних дорослого віку високі кількісні показники за шкалою аналітичності виявлено у 30,77\%. При прогнозуванні майбутнього респонденти здійснюють цілеспрямований аналіз своєї життєвої ситуації, обмірковують свої особистісні можливості та обмеження, а також враховують умови економічного розвитку в країні та соціального світу. У них розвинуте 
вміння до здійснення повного, всебічного аналізу своєї життєвої ситуації в теперішніх умовах, a їх перспективи мають ознаки стратегічного планування. В умовах професійної діяльності вони планують свою кар'єру в конкретній організації та чітко можуть визначити цілі та результати свого професійного розвитку. Середні показники аналітичності прогнозування виявлені у 53,85\% досліджуваних. Вони не завжди вміють здійснювати повний та всебічний аналіз свого майбутнього, але рефлексують наявні життєві ресурси й обмеження, встановлюють причинно-наслідкові особливості подій у власному житті, можуть приймати рішення тільки після ретельного вивчення всіх обставин. У професійній діяльності вони здійснюють прогнозування як оперативних, так і менш значущих для них цілей і планів, не завжди займаються стратегічним плануванням свого професійного розвитку. Низькі показники аналітичності в цій віковій групі дають можливість констатувати, що 15,38\% опитуваних передбачають своє майбутнє лише на рівні життєвих мрій і фантазій. Вміння до повного та всебічного аналізу досить мало розвинуте. Респонденти враховують тільки один-два аспекти життя, що впливає на здійснення їх життєвого прогнозу.

Шкала усвідомленості дозволяє визначити рівень розвитку здатності до інтроспекції в процесі прогнозування. Високі кількісні показники за шкалою усвідомленості виявлено в 19,24\% досліджуваних дорослого віку. Вони ретельно перевіряють правильність здійсненого прогнозу, визначають його успішність або неуспішність, аналізуючи зміст і достовірність. Усвідомлюють причинно-наслідкові співвідношення подій у своєму житті та на основі цього осмислення визначають способи досягнення життєвих та професійних цілей. Середній рівень розвитку усвідомленості прогнозування виявлено в 65,38\% опитуваних, які намагаються виявити лише найбільш глобальні явища соціального світу, що враховуються ними в процесах прогнозування. Опитувані з низькими показниками (15,38\%) за цією шкалою можуть замислюватись над правильністю власного прогнозу, однак рідко можуть осмислювати причинно-наслідкові зв'язки здійсненого прогнозування.

Гнучкість прогнозування відображає здатність респондентів до створення декількох варіантів прогнозу свого майбутнього та адаптації цих прогнозів до швидко змінних умов сьогодення. Високий рівень розвитку гнучкості прогнозування виявлено в 26,92\% досліджуваних. Вони встановлюють відповідність найбільш важливих для себе цілей і планів особистого та професійного життя до наявних ресурсів й обмежень. У випадках виявлення значної невідповідності, здатні оперативно корегувати життєві цілі та плани, вибудовувати нові стратегії поведінки відповідно до цих змін, за власною ініціативою переформатовують перспективи, прогнозують їх успішність. У процесі співбесіди було виявлено, що високий рівень гнучкості прогнозування відповідає за варіативність способів вирішення професійних завдань і відкритість до нового. У професійній діяльності такі спеціалісти швидко адаптуються до корпоративної культури, організаційних змін, умов праці тощо. Середні кількісні показники гнучкості $(61,54 \%)$ виявлено в досліджуваних, які до більшості стратегій реалізації своїх життєвих та професійних цілей створюють лише по одному плану. Втім, при виявленні значної невідповідності власних планів різним обставинам свого життя, можуть їх змінювати та корегувати. Досліджуваним на корегування своїх планів потрібен час й актуалізація особистісних ресурсів. Низький рівень розвитку гнучкості прогнозування був виявлений у 11,54\% досліджуваних. У них констатовано ригідність прогнозування та негнучкість адаптації життєвих і професійних прогнозів до умов економічного розвитку в країні та соціального світу. Зазвичай, вони створюють перспективи своєї кар'єри, проте, за умови виникнення непередбачуваних обставин, досить рідко здатні адаптувати їх до змін. Неможливість 
професійної самореалізації особистості в дорослому віці призводить до кризових переживань та фрустрації.

Перспективність прогнозування відображає темпоральні характеристики в життєвому просторі дорослих. Шкала перспективності прогнозування дозволяє дослідити вміння прогнозувати успішність реалізації життєвих цілей і планів у віддаленій перспективі. Досліджувані з високим рівнем розвитку перспективності (34,62\%) створюють чіткий прогноз реалізації своїх найбільш значущих цілей і планів, заснований на фактах, логічних судженнях та аналізі свого життєвого досвіду до віддалених періодів свого майбутнього (10-20 років), 3 середнім рівнем (50,00\%) - у найближчій і середній життєвій перспективі (від 5 років), 3 низьким рівнем (15,38\%) - переважно у найближчому майбутньому (3-5 років). У процесі співбесіди був виявлений взаємозв'язок між рівнем перспективності й частотою зміни місця роботи та професійних завдань. Досліджувані з високим рівнем перспективності не часто змінюють місце роботи та виконання професійних завдань, а респонденти з низьким рівнем, навпаки, схильні до ризику та частої зміни роботодавців, у тому числі до змін професійної діяльності. Але, у будь-якому випадку, перспективність прогнозування професійної діяльності в досліджуваних спрямована на успішність їх реалізації та досягнення поставлених цілей, хоча й у різний спосіб.

Доказовість прогнозування відображає процеси аналізу життєвих ситуацій минулого для здійснення більш точного прогнозу майбутнього. Кількість дорослих з високим рівнем розвитку доказовості - 40,38\%. Опитувані здійснюють прогнозування успішності реалізації життєвих цілей і планів, створюючи логічну послідовність «доказів», опираючись на власний досвід. Вони цілеспрямовано розробляють власні критерії оцінки правильності для себе обраних рішень. Середні кількісні показники розвитку доказовості виявлено в 51,92\% досліджуваних, які здійснювали спроби в найближчому минулому здійснити доказове прогнозування на основі аналізу близьких життєвих ситуацій. Вони виробляють окремі критерії визначення правильності обраних рішень. До низького рівня розвитку доказовості прогнозування було зараховано 7,69\% опитуваних, які здійснюють переважно відокремлений аналіз явищ особистісної та соціальної дійсності в процесі прогнозування та віднаходять лише окремі факти, що підтверджують правильність прогнозу.

Порівнюючи високі показники аналітичності та усвідомленості прогнозування (30,77\% та 19,24\% відповідно), встановлено, що досліджувані аналізують зовнішні та внутрішні умови прогнозування, проте не всі розуміють його зміст. Прогноз життєвих і професійних цілей та планів опитуваних поверховий. Це може свідчити про низький рівень саморефлексії, прагнення жити «тут і тепер», особистісну незрілість, зневіру в можливості професійної самореалізації в сучасних умовах. Крім того, високі показники перспективності (34,62\%) та аналітичності (30,77\%) свідчать про те, що життєві цілі, професійна кар'єра досліджуваних прогнозуються у довготривалій перспективі. Проте, не всі досліджувані проводять змістовний аналіз своїх особистісних обмежень та можливостей, умов соціального світу. 3 іншого боку, високий та середній показники гнучкості прогнозування демонструють здатність респондентів до варіативності творення прогнозів свого майбутнього та адаптації цих прогнозів до швидко змінних умов сучасності. Такі показники гнучкості прогнозування надають змогу досліджуваним корегувати життєві й професійні плани у довготривалій та середньотривалій перспективах, нівелюючи недостатній аналіз життєвої ситуації та середній рівень усвідомленості прогнозування. Результати цього аналізу презентовані на гістограмі (див. Рис. 1). 


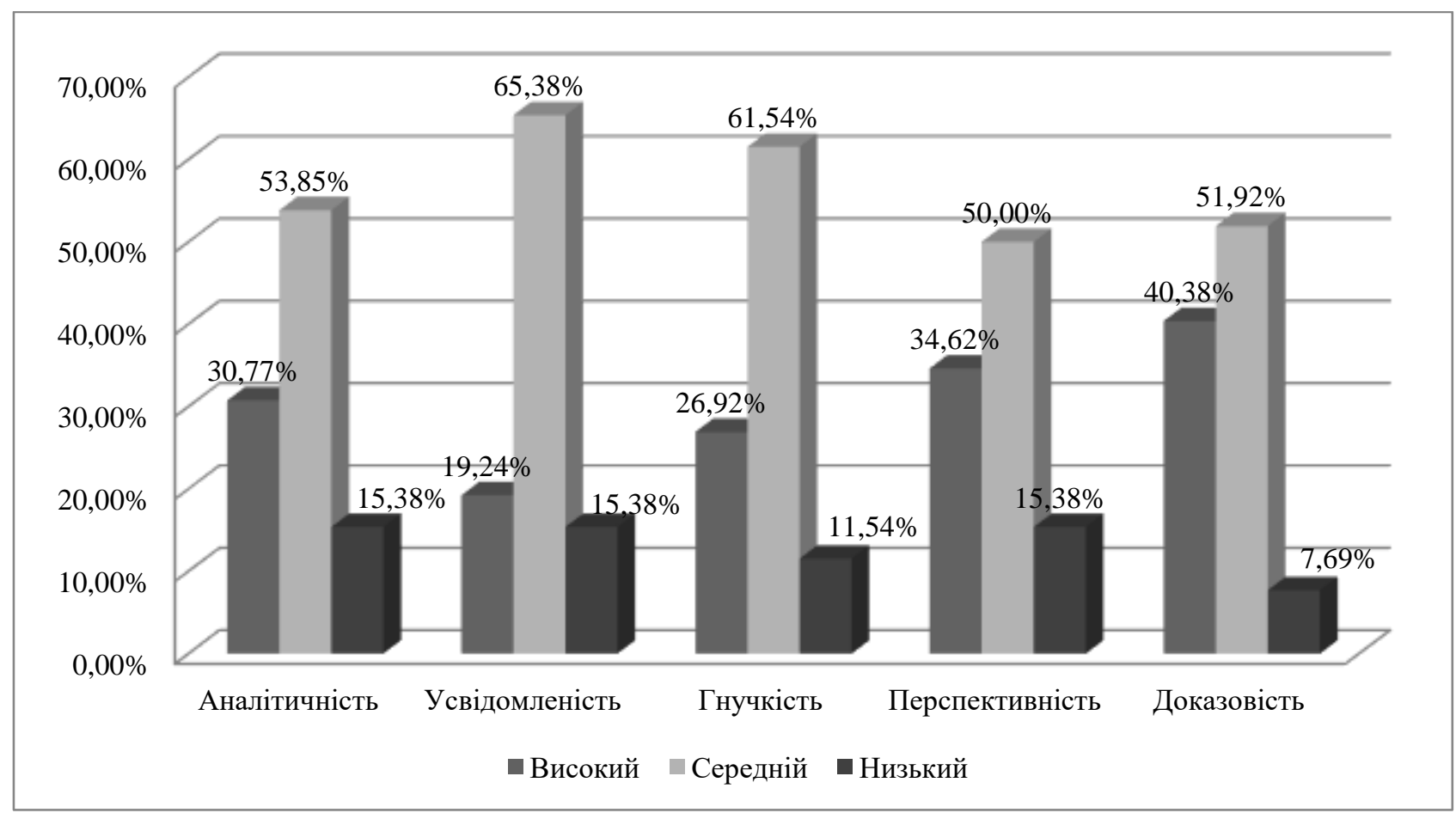

Рис. 1. Показники аналітичності, усвідомленості, гнучкості, перспективності та доказовості здатності до прогнозування досліджуваних дорослого віку

Згідно Л. Регуш, здатність до прогнозування - це здатність до складання життєвих проєктів і життєвої самореалізації (Регуш, 2003). У досліджуваній групі інтегральний показник здатності до прогнозування знаходиться на високому (40,39\%) та середньому (51,92\%) рівнях. Респондентів з низьким рівнем здатності до прогнозування в досліджуваній групі виявлено - 7,69\%. Результати кількісного розподілу презентовані на діаграмі (див. Рис. 2).

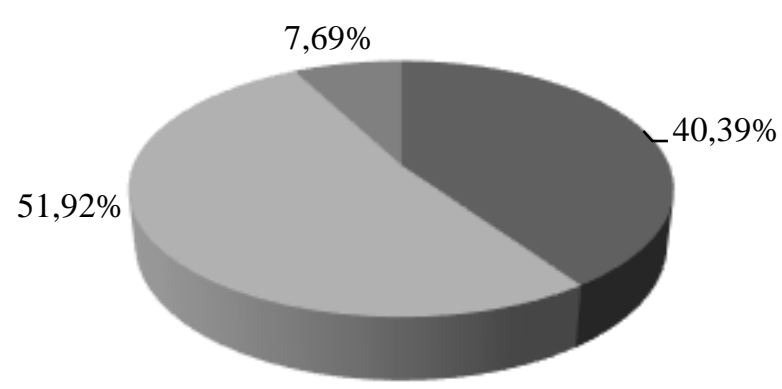

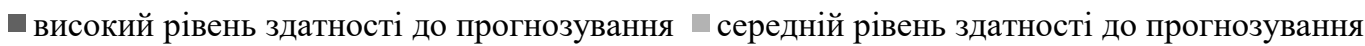

низький рівень здатності до прогнозування

\section{Рис. 2. Інтегральний показник рівня розвитку здатності дорослих до прогнозування}

У спілкуванні з респондентами з високим рівнем здатності до прогнозування був виявлений високий рівень результативності виконання професійних завдань. Крім того, ці досліджувані прогнозують своє успішне професійне майбутнє, можуть чітко окреслити чого 
вони прагнуть та як цього досягти. Їх професійні плани досяжні та реалістичні. Аналізуючи свою життєву ситуацію, вони більшою мірою враховують особистісні ресурси та обмеження, ніж зовнішні фактори. Досліджувані з середнім рівнем продемонстрували оптимальну здатність до складання професійних перспектив. Вони здатні ситуативно фокусуватися на своїх цілях та способах їх досягнення. Досліджувані з низьким рівнем прогностичної здатності прогнозують своє «успішне» професійне майбутнє, проте не можуть назвати чіткий план як досягти бажаного. У разі невдач звинувачують інших людей та зовнішні фактори. Плани досліджуваних з низьким рівнем менш реалістичні, проте не менш амбітні.

Спостерігається також різниця в ціннісних орієнтаціях досліджуваних з різним рівнем прогностичної здатності. Для досліджуваних 3 високими показниками здатності до прогнозування важлива самореалізація, менеджмент, ефективність праці, підтримка балансу «життя-робота», пізнання, творчі завдання тощо, а для досліджуваних з низьким рівнем заробіток, комфортні умови праці, чіткість та зрозумілість у виконанні професійних завдань тощо.

\section{Висновки}

Отже, результати проведеного теоретичного дослідження показали, що проблема прогнозування професійної діяльності дорослих у психології не має ще широкого обсягу вивчення. Обгрунтовано, що прогнозування є розумовою активністю людини, яка спрямована на передбачення майбутнього. Відповідно життєве прогнозування визначено як передбачення особистістю власного майбутнього, своїх життєвих цілей і планів.

Встановлено, що прогнозування $є$ основою цілеспрямованої професійної діяльності людини та іiі професійного становлення. Прогнозування професійної діяльності людини визначено як її особистісне уявлення, оцінка та тлумачення кар'єрного зростання.

Від розвинутої здатності дорослої особистості до прогнозування власного майбутнього, своїх життєвих цілей та планів залежить прогнозування iї професійної самореалізації. Доведено, що здатність до прогнозування визначає успішність та результативність професійної діяльності особистості дорослого віку.

За результатами проведеного емпіричного дослідження констатовано, що в опитуваних дорослого віку здатність до прогнозування має різні якісні показники. Досліджувані 3 високими якісними показниками продемонстрували здатність до цілеспрямованого, повного та всебічного аналізу свого життя, побудови реалістичних життєвих та професійних цілей і планів. Вони здатні адаптуватися до швидких змін сьогодення та корегувати відповідно з ними свої життєві та професійні перспективи. Досліджуваним з середнім рівнем властива здатність до здійснення аналізу найбільш значущих подій свого життя. У разі виникнення непередбачуваних обставин вони здатні корегувати свої цілі на майбутнє. Досліджувані 3 низькими показниками прогнозують власне майбутнє без повного та всебічного аналізу своєї життєвої ситуації, їх перспективи фантазійні та мало досяжні. Вони не здатні самостійно будувати реалістичні плани, що негативно впливає на їх особистісне та професійне зростання. Виходячи з вищевикладеного, для актуалізації здатності до прогнозування в досліджуваних 3 низькими якісними показниками необхідна подальша психологічна підтримка та застосування розвивальних психологічних програм.

Перспективами подальших досліджень є вивчення проблеми гендерних особливостей прогнозування професійної діяльності дорослих. 


\section{Література}

1. Абульханова-Славская, К. (1980). Деятельность и психология личности. Москва : Наука.

2. Анфалов, Е.В. (2016). К вопросу формирования рефлексивно-прогностической компетенции у обучающихся в военном вузе. I междунар. Науч. Конф. «аспекты и тенденции педагогической науки» (Санкт-петербург, 20-23 декабря 2016г.). (c. 175-178). Г. Санкт-петербург : Свое издательство.

3. Батраченко, I. (1996). Психологія розвитку антищипаціï людини. Дніпро : Своє видавництво.

4. Бестужев-Лада, И.В. (1982). Рабочая книга по прогнозированию. Москва : Мысль.

5. Блохіна, I.O. (2012). Психологічні чинники становлення професійно-етичних настановлень майбутніх фахівців $з$ управління навчальними закладами. (Дис. канд. психол. наук). Київ.

6. Брушлинский, А.В. (1979). Мылление и прогнозирование. Москва : Мысль.

7. Булах, I. (2016). Психологія особистісного зростання підлітків: реалії та перспективи. Вінниця : Нілан-ЛТД.

8. Вірна, Ж.П. (2004). Мотиваційно-смислова регуляція у професіоналізації психолога. (Автореф. дис. доктора психол. наук). Київ.

9. Головаха, Е.И., \& Панина, Н.В. (2002). Психология человеческого взаимопонимания. Киев : Институт социологии НАН Украины.

10. Гріньова, О. (2018). Психологія проектування життєвого шляху: юнаџький вік. Київ : Нілан-ЛТД.

11. Захаров, А.В. (2009). Формирование прогностических умений студентов педагогического вуза: на материалах изучения дисциплин психолого-педагогического цикла. (Дис. канд. пед. наук). Ишим.

12. Кошонько, Г.А. \& Поробок, О.О. (2018). Прогностичні вміння в структурі професійної діяльності майбутніх психологів. Збірник наукових праць національної академії державної прикордонної служби україни. Серія: Психологічні науки, 2, 130-142. Режим доступу: http://elar.khnu.km.ua/jspui/handle/123456789/6811

13. Краева, М.Ю. (1999). Динамика прогностических способностей у студентов психологов в образовательном процессе вуза. (Дис. канд. психол. наук). Астрахань.

14. Ломов, Б.Ф., \& Сурков, Е.Н. (1980). Антиципащия в структуре деятельности. Москва : Наука.

15. Ляхова, М. (2010). Психологические составляющие жизненной стратегии личности. Вестник КЕМГУ, 3(43), 83-90.

16. Максименко, С. (2010). Прогнозування розвитку особистості як наукова проблема. Наук. Вісник миколаївського держ. Пед. Ун-ту ім. В.О. Сухомлинського, 2 (5), 3-19.

17. Помиткіна, Л. (2013). Психологія прийняття особистістю стратегічних життєвих pimень. (Монографія). Київ : Видавництво Національного авіаційного університету. Кафедра.

18. Регуш, Л.А. (2003). Психология прогнозирования: успехи в познании будущего. Санктпетербург : Речь.

19. Соколова, Н.Ф. (2004). Формирование прогностических умений у студентов колледжей в условиях дистанционного обучения математике. (Автореф. дис. канд. пед. наук). Москва.

20. Чернобровкіна, В. (2012). Психологія особистісної свободи: монографія. Луганськ : Видво ДЗ «ЛНУ імені Тараса Шевченка».

\section{References}

1. Abulhanova-Slavskaja, K. (1980). Dejatelnost i psihologija lichnosti [Activity and psycholony of personality]. Moscow : Nauka [in Russian].

2. Anfalov, E.V. (2016). K voprosu formirovaniia refleksivno-prognosticheskoi kompetentsii u obuchaiushchikhsia $\mathrm{v}$ voennom vuze [On the issue of the formation of reflexive-prognostic competence among students at a military university]. Proceeding from: I mezhdunar. nauch. 
konf. "Aspekty $i$ tendentsii pedagogicheskoi nauki» - I international scientific conference «Aspects and trends of pedagogical science» (Saint Petersburg, december 20-23th, 2016). (pp. 175-178). Saint Petersburg : Personal publishing house [in Russian].

3. Batrachenko, I. (1996). Psykholohiia rozvytku antytsypatsii liudyny [Psychology of development of anticipation of people]. Dnipro : Personal publishing house [in Ukrainian].

4. Bestuzhev-Lada, I. (1982). Rabochaia kniga po prognozirovaniiu [Forecasting workbook]. Moscow : Mysl [in Russian].

5. Blokhina, I.O. (2012). Psykholohichni chynnyky stanovlennia profesiino-etychnykh nastanovlen maibutnikh fakhivtsiv $\mathrm{z}$ upravlinnia navchalnymy zakladamy [Psychological factors of formation of professional and ethical attitudes of future specialists in the management of educational institutions]. Candidate's thesis. Kyiv [in Ukrainian].

6. Brushlinskii, A. (1979). Myshlenie i prognozirovanie [Thinking and forecasting]. Moscow : Mysl [in Russian].

7. Bulakh, I. (2016). Psykholohiia osobystisnoho zrostannia pidlitkiv: realii ta perspektyvy [Psychology of special development of children: realities and perspectives]. Vinnytsya : NilanLTD [in Ukrainian].

8. Virna, Z.P. (2004). Motyvatsiino-smyslova rehuliatsiia u profesionalizatsii psykholoha [Motivational and semantic regulation in the professionalization of the psychologist]. Extended abstract of doctor's thesis. Kyiv [in Ukrainian].

9. Golovaha, E.I., \& Panina, N.V. (2002). Psihologija chelovecheskogo vzaimoponimanija [the psychology of human understanding]. Kyiv : Institute of sociologii NAN Ukraini [in Russian].

10. Hrinova, O. (2018). Psykholohiia proektuvannia zhyttievoho shliakhu: yunatskyi vik [psychology of the design of the life path: yunatskiy vik]. Kyiv : Nilan-LTD [in Ukrainian].

11. Zakharov, A.V. (2009). Formirovanie prognosticheskikh umenii studentov pedagogicheskogo vuza na materialakh izucheniia distsiplin psikhologo-pedagogicheskogo tsikla [Formation of prognostic skills of students of a pedagogical university: on the materials of studying the disciplines of the psychological and pedagogical cycle]. Candidate's thesis. Ishim [in Russian].

12. Koshonko, H.A., \& Porobok, O.O. (2018). Prohnostychni vminnia v strukturi profesiinoi diialnosti maibutnikh psykholohiv [Prognostic thinking in the structure of professional activity of the future psychologists]. Zbirnyk naukovykh prats natsionalnoi akademii derzhavnoi prykordonnoi sluzhby ukrainy. Seriia: psykholohichni nauky - Collection of scientific works of the national academy of the state border guard service of ukraine. Series: psychological sciences, 2, 130-142. Retrived from http://elar.khnu.km.ua/jspui/handle/123456789/6811[in Ukrainian].

13. Kraeva, M.U. (1999). Dinamika prognosticheskikh sposobnostei u studentov psikhologov v obrazovatelnom protsesse vuza [The dynamics of predictive abilities among psychology students in the educational process of the university]. Candidate's thesis. Astrakhan [in Russian].

14. Lomov, D.F., \& Surkov, E.N. (1980). Antitsipatsiia $v$ strukture deiatelnosti [Anticipation in the structure of activity]. Moscow : Nauka [in Russian].

15. Ljahova, M. (2010). Psihologicheskie sostavljajushhie zhiznennoj strategii lichnosti [Psychological components of a personality's life strategy]. Vestnik KEMGU - Scientific bulletin of kemerovo state university, 3(43), 83-90 [in Russian].

16. Maksymenko, S. (2010). Prohnozuvannia rozvytku osobystosti yak naukova problema [Predicting the development of special features as a science problem]. Nauk. Visnyk mykolaivskoho derzh. Ped. Un-tu im. V. O. Sukhomlynskoho - Scientific bulletin V.O. Sukhomlynskyi mykolaiv national university, 2(5), 3-19 [in Ukrainian].

17. Pomytkina, L. (2013). Psykholohiia pryiniattia osobystistiu stratehichnykh zhyttievykh rishen [Psychology of acceptance of the specialty of strategic life decisions]. Kyiv : Vydavnytstvo Natsionalnoho aviatsiinoho universytetu. Kafedra [in Ukrainian].

18. Regush, L.A (2003). Psikhologiia prognozirovaniia uspekhi v poznanii budushchego [Psychology of forecasting: advances in understanding the future]. Saint Petersburg : Rech [in Russian]. 
19. Sokolova, N.F. (2004). Formirovanie prognosticheskikh umenii u studentov kolledzhei v usloviiakh distantsionnogo obucheniia matematike [formation of predictive skills among college students in the context of distance learning mathematics]. Extended abstract of candidate's thesis. Moscow [in Russian].

20. Chernobrovkina, V. (2012). Psykholohiia osobystisnoi svobody [Psychology of personal freedom]. Luhansk : Vyd-vo DZ «LNU imeni Tarasa Shevchenka» [in Ukrainian].

\author{
ABILITY TO FORECAST AS A CONDITION FOR SUCCESSFUL PROFESSIONAL \\ ACTIVITY OF ADULTS \\ Ievgeniia Rezvykh \\ Postgraduate Student of the Department of Theoretical and Counselling Psychology \\ National Pedagogical Dragomanov University \\ 9, Pyrogov Str., Kyiv, Ukraine, 01601 \\ rezvykh.evgeniya@gmail.com, http://orcid.org/0000-0001-5316-0516
}

\begin{abstract}
The article presents the results of a theoretical study of psychological sources on the problem of predicting the professional activities of adults. Theoretical and methodological provisions of the study of forecasting and life forecasting as psychological phenomena in the works of foreign and domestic psychologists are revealed. The content and essence of forecasting human activity and professional activity are determined. There are two stages of studying the research topic: classical and modern. Representatives of classical psychology reveal the prediction of human activity in the context of its functioning at the sensory and mental levels of mental reflection. Modern psychologists in their research emphasize the development of prognostic abilities and skills of young people and adults in the process of professional training. The focus is on the relationship between the ability of an adult to predict their own future, their life goals and plans with the prediction of their professional activities. It has been proven that the ability to predict is a key condition for successful professional activity of an individual in adulthood. Empirically studied psychological features of forecasting life and professional plans of adults and their successful implementation. According to the results of the analysis of analytical, awareness, flexibility, prospects and evidence of life and professional forecasting, it is established that in future forecasts the analytical function of adults is limited, future awareness is related to causation, flexibility of goals and plans determines adaptability to rapid change, perspective has temporal characteristics in the living space of adults, and provability reflects the processes of analysis of life situations of the past to make a more accurate forecast of the future. It is stated that only a high integrated indicator of the ability to professionally predict adults can ensure the success of their professional self-realization. The importance for further study of the process of forecasting professional activity by members of different sexes is emphasized.

Keywords: forecasting, life forecasting, forecasting of professional activity, prospects of life and professional forecasting, ability to forecast, forecasting of successful professional activity, personality of adulthood.
\end{abstract}

Подано 10.12.2021

Рекомендовано до друку 16.12.2021 